\title{
Seminário internacional de bibliotecas digitais
}

Nos dias 18, 19 e 20 de setembro de 2007 foi realizado o Seminário Internacional de Bibliotecas Digitais Brasil, em São Paulo, no Centro de Convenções Rebouças.

As bibliotecárias Maria Italia Causin, Marcia Pilnik e Floripes de Moura Pacheco participaram do evento, que teve como objetivo promover a discussão entre profissionais das áreas de Biblioteconomia e Ciência da Informação, Ciências da Computação e outros ligados à área de Tecnologia da Informação sobre a temática das Bibliotecas Digitais.

Foram explorados temas como iniciativas em Arquivos Abertos (Open Archives) e a importância do desenvolvimento de Bibliotecas Digitais como facilitadores da inclusão social; questões legais de acesso livre, repositórios institucionais, convergência de mídias digitais, preservação digital, tecnologia, padrões e formatos utilizados na estrutura de Bibliotecas Digitais e projetos em andamento no cenário nacional e internacional.

0 avanço da tecnologia na área de digitalização permitirá ainda a viabilização do acesso à informação para deficientes visuais, tema este também discutido em apresentações orais durante o Seminário.

As discussões sobre a preservação e a digitalização do material bibliográfico, seja ele raro e/ou antigo, deixaram clara a necessidade crescente de um trabalho conjunto de bibliotecários, conservadores, restauradores e técnicos em digitalização, para que possamos disponibilizar informações de uma forma cada vez mais prática e segura para usuários da Internet.

A exemplo disso, lembramos a iniciativa de um grande provedor de busca - Google - que, através de sua Pesquisa Google Livros, preocupa-se com a organização da informação no mundo, utilizando-se de conteúdos em domínio público on-line, oferecidos por diferentes instituições.

Para os livros que ainda não se enquadram nessa situação este provedor, em parceria com diferentes editoras (no Brasil, em torno de 60), permite que o usuário da Internet visualize trechos de livros, respeitando assim os direitos autorais.

0 Instituto de Estudos Brasileiros, engajado nesta realidade, e preocupando-se também com o aperfeiçoamento no atendimento ao seu usuário, tem desenvolvido diferentes projetos, entre eles a criação da Biblioteca Digital no site do IEB, tendo como serviços de apoio a Biblioteca e o Setor de Informática.

A Biblioteca Digital disponibiliza aos pesquisadores e ao público em geral o conteúdo de livros de diversas áreas do 
conhecimento, em domínio público, publicados a partir do século XVI, que integram o seu acervo. Os livros foram digitalizados a partir de solicitações de pesquisadores de várias instituições e usuários da Biblioteca. Não constituem um conjunto temático de obras e nem resultam de projetos de pesquisa desenvolvidos no IEB mas, sem dúvida, oferecem a oportunidade de o usuário tomar conhecimento do rico acervo que compõe sua Biblioteca, sem contar a facilidade de dispor das informações com maior rapidez e segurança.

Outra iniciativa que tem sido muito elogiada é a implantação, na Biblioteca, do Sistema de Solicitação de Obras pelo usuário.

Totalmente informatizado, utilizando como chave principal o número do CPF, ele possibilita o cadastramento do usuário, que deve introduzir os seus dados pessoais uma única vez, possibilitando a solicitação de obras do acervo, sejam quais forem os materiais necessários - livros, revistas - cadastrados no Dedalus - Banco de Dados Bibliográficos da USP e que, por sua vez, se encontram na nossa Base Local.

Temos certeza de que, dentro desse cenário de avanço das grandes tecnologias, o IEB tem se mostrado empenhado em participar como facilitador da inclusão social, permitindo, cada vez mais, que seus usuários se aproximem do seu acervo de maneira prática e eficiente.

Maria Italia Causin

Marcia Pilnik

Floripes de Moura Pacheco 